April 2019

\title{
Social Determinants of Indigenous Health and Indigenous Rights in Policy: A Scoping Review and Analysis of Problem Representation
}

Emma George

Flinders University, emma.george@flinders.edu.au

Tamara Mackean

Flinders University, tamara.mackean@flinders.edu.au

Fran Baum

Flinders University, fran.baum@flinders.edu.au

Matt Fisher

Flinders University, matt.fisher@flinders.edu.au

\section{Recommended Citation}

George, E. , Mackean, T. , Baum, F. , Fisher, M. (2019). Social Determinants of Indigenous Health and Indigenous Rights in Policy: A Scoping Review and Analysis of Problem Representation. The International Indigenous Policy Journal, 10(2) .

DOI: $10.18584 /$ iipj.2019.10.2.4 


\title{
Social Determinants of Indigenous Health and Indigenous Rights in Policy: A Scoping Review and Analysis of Problem Representation
}

\begin{abstract}
Despite evidence showing the importance of social determinants of Indigenous health and Indigenous rights for health and equity, they are not always recognised within policy. This scoping review identified research on public policy and Indigenous health through a systematic search. Key themes identified included the impact of ongoing colonisation; the central role of government in realising rights; and the difficulties associated with the provision of mainstream services for Indigenous Peoples, including tokenism towards Indigenous issues and the legacy of past policies of assimilation. Our approach to problem representation was guided by Bacchi (2009). Findings from the review show social determinants of Indigenous health and Indigenous rights may be acknowledged in policy rhetoric, but they are not always a priority for action within policy implementation.
\end{abstract}

\section{Keywords}

social determinants of Indigenous health, rights, self-determination, problem representation

\section{Acknowledgments}

This work was supported by the NHMRC Centre of Research Excellence on the Social Determinants of Health Equity: policy research on the social determinants of health equity (APP1078046). The authors acknowledge the contribution of peer reviewers and thank them for their feedback and recommendations, which enhanced the quality of the article.

\section{Disclaimer}

The authors of this article acknowledge that we live and work on the traditional lands of the Kaurna people of the Adelaide plains.

\section{Creative Commons License}

Creative Commons Attribution-Noncommercial-No Derivative Works 4.0 License

This work is licensed under a Creative Commons Attribution-Noncommercial-No Derivative Works 4.0

License. 


\section{Social Determinants of Indigenous Health and Indigenous Rights in Policy: A Scoping Review and Analysis of Problem Representation}

According to the Commission on the Social Determinants of Health (2008), the social determinants of health are the conditions in which people are born, grow, live, work, and age. Inequalities in health are caused by the unfair distribution of power, income, goods, and services, and consequences are evident in limited access to health care, education, work, leisure, and healthy communities. In addition, there is growing recognition of the social determinants of Indigenous health, which recognise the adverse health impacts of issues such as racism, and the health benefits of strong cultural identity, connection to country, sovereignty, and Indigenous knowledges (Anderson, Baum, \& Bentley, 2007; Carson, Dunbar, Chenhall, \& Bailie, 2007). These perspectives reflect an Australian Aboriginal and Torres Strait Islander definition of health, which is:

Not just [about] the physical well-being of an individual but refers to the social, emotional, and cultural well-being of the whole community, in which each individual is able to achieve their full potential as a human being, thereby bringing about the total well-being of their community. (National Aboriginal Community Controlled Health Organisation, 2006, Aboriginal Health section, para. 1)

Similarly, Durie (1985) described a Maori definition of health founded upon spiritual, psychic, and family dimensions, rather than just a physical biomedical approach to health. He emphasised the importance of cultural factors that affect the health of communities as a whole. In addition, Canadian research on health as defined by First Nations people showed that health transcends an individual perspective to include family, community, and the environment (Levesque \& $\mathrm{Li}$, 2014; Levesque, Li, \& Bohemier, 2013).

Research has shown there are significant deficits in conceptualisation and implementation of social determinants of health in policy. Carter, Hooker, and Davey (2009) analysed the way that social determinants were acknowledged, audited, recommended, or linked with aims in cancer policy. In their view, where social determinants were acknowledged, the naming of social determinants appeared to be ritualistic, "an incantation to be said before the policy or plan got on with the real business of reducing risk” (p. 1451). They explained that inclusion of social determinants in a policy's aims did not necessarily lead to recommendations for action. Another study by Phillips et al. (2016) explored social determinants in Australian child and youth health policies. They found that all of the policies analysed acknowledged social determinants to some extent; however, the strategies proposed to address these issues were few and limited in scope. They concluded that the broader determinants of health are either considered outside the scope of the health sector, or not a priority. A third study by Fisher, Baum, MacDougall, Newman, and McDermott (2016) found that, although social determinants were generally acknowledged in Australian health policy documents, "policies generally did not recognise broader policy settings affecting the overall distribution of socioeconomic resources as determinants of health inequities" (p. 553). In addition, key determinants of Indigenous health such as racism, cultural identify, or strong community governance structures were very rarely identified in policies (Carson et al., 2007). The lack of social determinants in policy is prevalent across colonised countries and Indigenous Peoples globally have experienced health inequity and lower life expectancy than non-Indigenous people. Policy research can advance understanding of more effective ways to address social determinants of health and 
promote the fair distribution of health in society (Baum \& Friel, 2014). However, research has shown that the implementation of policy does not always result in effective action on health inequities affecting Indigenous Peoples (Comino, Knight, \& Webster, 2012; Dwyer, Kelly, Willis, \& Mackean, 2011; Osborne, Baum, \& Brown, 2013; Ziersch, Gallaher, Baum, \& Bentley, 2011). This may be in part because policy implementation fails to support self-determination (Tynan, 2013) and does not attend to social determinants of Indigenous health (Carson et al., 2007). In this article, we recognise similar experiences of discrimination and inequality across high-income colonised countries; therefore, we have focused our research on policy and social determinants of health in Australia, New Zealand, Canada, and the United States of America. Collectively, we acknowledge there are Indigenous Peoples within each nation with shared experiences of inequity but with diverse cultural identities.

The United Nations (2007) adopted the United Nations Declaration on the Rights of Indigenous Peoples (UNDRIP) in 2007. This affirmed the dignity and rights of the world's Indigenous Peoples. The Declaration addressed both individual and collective rights including equality and freedom from discrimination, self-determination, and the maintenance and strengthening of Indigenous institutions (Healey, 2014). Self-determination is the right to freely determine political status and to pursue economic, social, and cultural development (Australian Human Rights Commission, n.d.). The Declaration has been described as important because it opposes discrimination and assimilation policies; however, Davis (2007) acknowledged it is a non-binding human rights instrument, and it was not initially endorsed by the Australian, New Zealand, Canadian, or American governments.

In order to understand what does and does not work to improve Indigenous health, we must examine the extent to which Indigenous knowledge, a vital component, is incorporated into action on social determinants of health. Durie (2005) described Indigenous knowledge as dynamic and based on collective and holistic principles, rather than individual or reductionist ones (Hart, 2010). Indigenous knowledge is shared and communicated orally and through culture. It is stored in "people's memories and activities and is expressed in stories, songs, folklore, proverbs, dances, myths, cultural values, beliefs, rituals, community laws, local language and taxonomy, agricultural practices, equipment, materials, plant species and animal breeds" (Grenier, 1998, p. 2). Sherwood (2010) and Hart (2010) both described Indigenous knowledge as relational and communally oriented, as well as founded on notions of respect, responsibility, and reciprocity. Hernandez (2012) explained that Indigenous knowledge is fundamentally different than Western scientific knowledge, and that research has most often taken power and legitimacy away from Indigenous knowledge. However, Indigenous knowledge is important in understanding social determinants of Indigenous health. It is necessary in promoting policy implementation and action aligned with broader definitions of health and well-being.

\section{Focus of Literature Review}

Bacchi (2009) proposed that policy analysis should explore the ways particular issues are conceived as "problems," how problems are represented in policy, and how we are governed by these problem representations. We began with a literature review to scope and analyse the literature that focuses on policy relevant to Indigenous people globally, the social determinants of health, and Indigenous rights. This review sought to answer the question: In what ways are social determinants of Indigenous health and Indigenous rights recognised in public policy? Then we drew on a Bacchian approach to analyse problem representation in order to identify the ways in which problems have been framed. 


\section{Methods}

\section{Search Strategy}

A scoping review of the literature allows synthesis of research evidence to map existing literature, summarise knowledge gaps, and make recommendations for future research (Peters et al., 2015). Our search strategy was designed to identify literature addressing themes of Indigenous rights and social determinants of Indigenous health in policy relevant to the last decade. The authors' knowledge and experience with Australian policy informed the search; however, we sought literature from comparable colonised countries: New Zealand, Canada, and the United States. We recognise that Indigenous Peoples in these countries are subject to health inequities similar to those affecting Aboriginal and Torres Strait Islander people in Australia (Jackson Pulver et al., 2010). Therefore, the search strategy was not limited to literature only in the Australian context. In collaboration with a university librarian, subject categories and key search terms (shown in Table 1) were identified and the search was initially run through these databases: Medline, Scopus, Informit, ProQuest, and Australian Policy Online. Sources that were not in English were excluded.

Table 1. Literature Search Categories and Terms

\begin{tabular}{|c|c|}
\hline Categories & Search Terms \\
\hline Health & health* OR wellbeing OR "well-being" \\
\hline Policy & $\begin{array}{l}\text { policy OR policies OR "self determin*" OR decoloni* OR colonis* OR } \\
\text { coloniz* OR assimilat* OR power* OR empower* }\end{array}$ \\
\hline Social & social $^{*}$ OR socio* OR determinant* OR marginali* OR poverty OR welfare \\
\hline $\begin{array}{l}\text { Determinants of } \\
\text { Health }\end{array}$ & 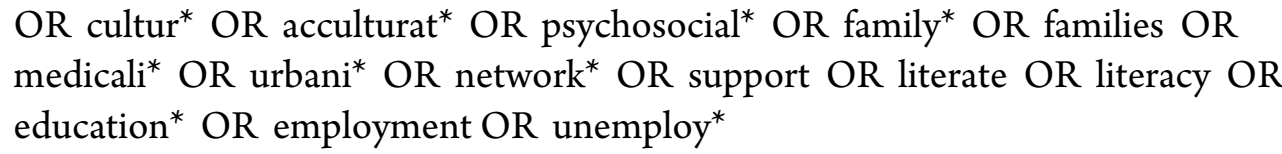 \\
\hline Indigenous & $\begin{array}{l}\text { Indigenous OR Indigeneit* OR Aborigin* OR "Torres Strait*" OR "First } \\
\text { Nation*" OR "First People*" OR Maori OR "American Indian*" OR Inuit* } \\
\text { OR Métis }\end{array}$ \\
\hline
\end{tabular}


Alerts were created through the databases to identify any new records as they were published. Additional searches were run through the Closing the Gap Clearinghouse website and Australian Indigenous Health InfoNet to identify Australian records that may have been missed by the larger databases. In order to search for further literature related to New Zealand, Canada, and the United States, we included a targeted search within two relevant international peer-reviewed journals. The peer review of this article led to suggestions for additional sources, which were included in the results. Records were excluded if they focused on program evaluation and outcomes rather than on policy, or if the literature focused on recommendations for policy in the future, rather than research on current policy. This narrowed the results to focus on policy and implementation rather than service evaluation. Grey literature from a variety of sources was included to add critical commentary and insight on policy implementation. All records were imported into NVivo11 qualitative analysis software and coded using thematic analysis. The process and results of the search strategy are shown in Figure 1.

\section{Thematic Analysis}

An initial thematic analysis of the literature was done using NVivo software. A coding framework was developed that allowed for flexibility and development of additional codes to capture new concepts as they emerged. Themes that were specifically sought from the literature included social determinants of Indigenous health, Indigenous rights, and self-determination. Other themes on colonisation, the role of government, and the provision of mainstream services emerged from the data. In addition, records were cross-examined to explore themes that were missing or clustered in only certain types of literature (e.g., peer-reviewed literature, government and non-government reports, policy audits, commentaries, etc.). The analysis enabled identification of gaps in the literature.

We then used Bacchi's "What's the Problem Represented to be" approach to critically analyse results from the thematic analysis and to identify the ways in which problems have been framed (Bacchi, 2009). Problem representation can be explicit or implicit, and it can be underpinned by assumptions that lead some things being problematized and others not. Therefore, analysis was both an inductive data driven approach to identify themes that emerged from the literature, and deductive where preconceived themes were sought from the literature as recommended by multiple authors (Dixon-Woods, Agarwal, Jones, Young, \& Sutton, 2005; Saks \& Allsop, 2007). Bacchi’s (2009) approach allowed us to explore the following questions:

- How are Indigenous Peoples, health, and rights represented as policy problems?

- How have such problem representations come about?

- What are the effects produced by such problem representation in limiting policy goals and strategies, or silencing other alternatives? 
Records identified through database search $(n)$ : Medline (137), Scopus (217), Informit (372),

ProQuest (125), Australian Policy Online (220), CTG Clearinghouse (58),

Australian Indigenous HealthInfoNet (433)

$$
(n=1,130)
$$

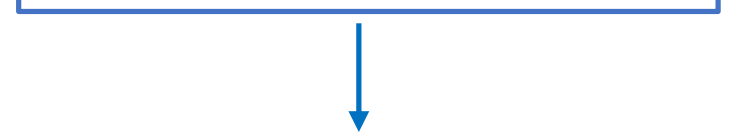

Records screened by title $(n)$ :

Medline (31), Scopus (29), Informit (41),

ProQuest (26), Australian Policy Online (43),

CTG Clearinghouse (13), Australian Indigenous

HealthInfoNet (20)

$(n=183)$
Records identified through journal search $(n)$ : The International Indigenous Policy Journal (45), Journal for Health Policy and Management (49)

$$
(n=94)
$$

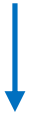

Records screened by title $(n)$ : The International Indigenous Policy Journal (14), Journal for Health Policy and Management (3)

$$
(n=17)
$$

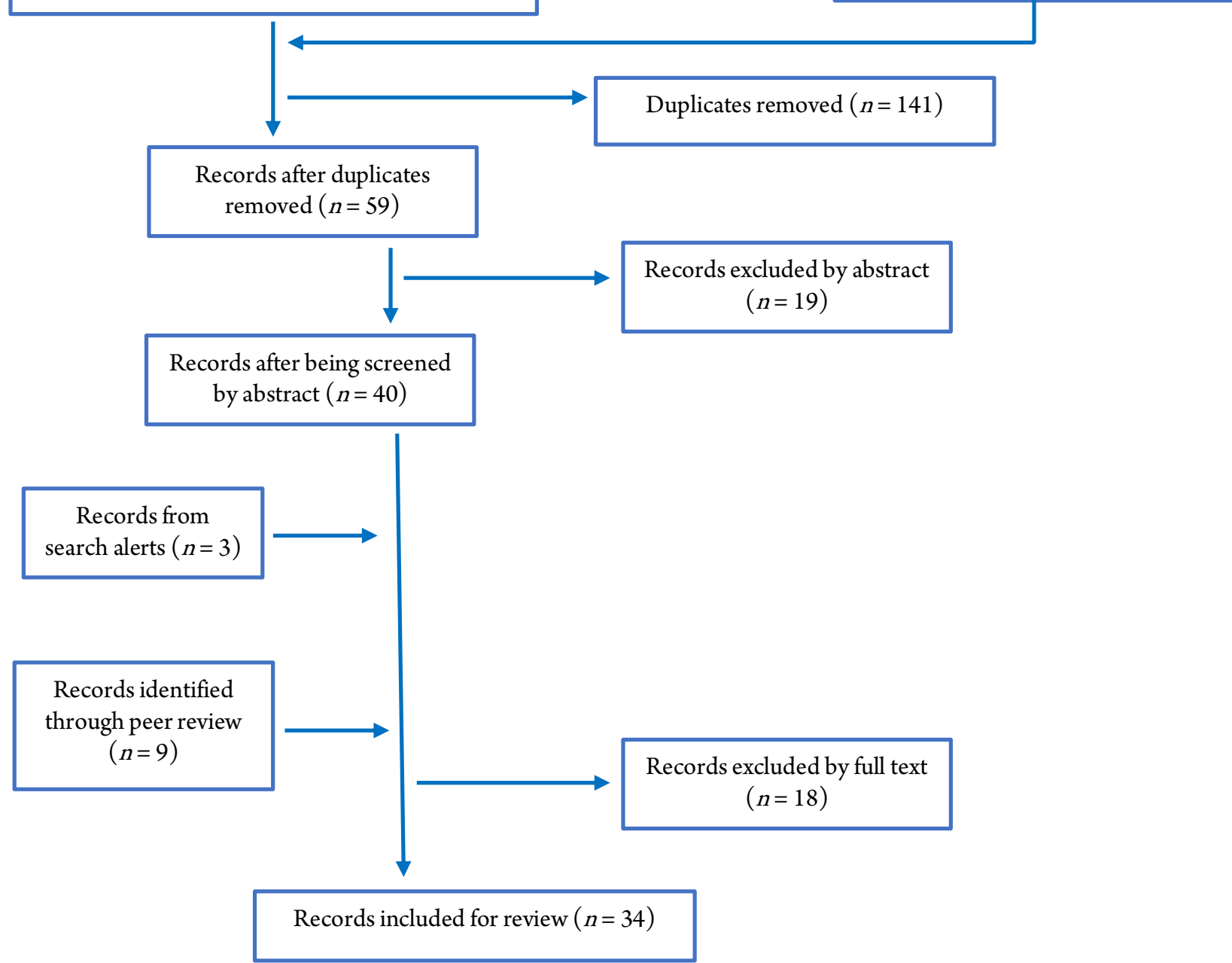

Figure 1. Scoping review search strategy and results. 


\section{Results}

A total of 34 records were included in this scoping review (Figure 1). Records included an edited book chapter, peer-reviewed journal articles, government and non-government reports, commentaries, conference papers, and a public lecture. The diverse genres provide alternate perspectives on policy and implementation with regard to social determinants and Indigenous populations. Among the records, 19 were primarily focused on an Australian context, 10 Canadian (one of these included a comparison with Norway, and two others compared the Canadian context with other colonised countries), three from New Zealand (one of these included a comparison to social policy in Fiji), and two from the United States. The included sources are provided in Table 2.

\section{Overview}

As expected, themes of social determinants of health, Indigenous rights, and self-determination were discussed throughout the literature. Our results showed that the ways that social determinants of Indigenous health and Indigenous rights are recognised in policy are contested. Much of the literature recognised social determinants of Indigenous health, especially the importance of culture. However, even when social determinants and rights are written into policy, this does not always result in action in these areas (Australian Institute of Health and Welfare, 2016; Cooper, 2011; Klein, 2015; Robertson, Conigrave, Ivers, Usher, \& Clough, 2012; D. Smith, 2007).

In addition, the ongoing impact of colonisation emerged as a central theme. The literature highlighted a contrast between a colonising deficit-based approach to policy and one that stresses the value and strength of Indigenous cultures and individual or community capabilities (Carter et al., 2009; Klein, 2015; Sullivan, 2011). Even though cultural inheritance and maintenance may be acknowledged in policy as important for individuals (Australian Institute of Health and Welfare, 2016), Cooper (2011) argued that Indigenous expression of culture through language and use of traditional lands "are not generally considered indicators of 'progress' by governments" (p. 14). He went on to suggest that culture in this sense has been seen as a problem, rather than part of the solution, and therefore has been excluded from policy.

Other themes that emerged from the data analysis focused on the role of the government and on the provision of mainstream services for Indigenous Peoples. Within both themes, the literature reviewed emphasised a need for commitment across governments and communities to working together (Bishop, Vicary, Browne, \& Guard, 2009; Cooper, 2011; Kelaher et al., 2015; Meo-Sewabu \& Walsh-Tapiata, 2012; Victorian Council of Social Service, 2016). However, there was also a consistent view that the depth or quality of collaboration, consultation, engagement, involvement, partnership, or participation reported was variable. Browne et al. (2017) highlighted that policy actors in their study advocated for "genuine" or "meaningful" partnerships, suggesting that previous partnerships had not reflected these characteristics. 
Table 2. Summary of Sources Included in the Analysis

\begin{tabular}{|c|c|c|c|c|}
\hline Author & Date & Country & Source Type & Themes Identified \\
\hline 1. Anderson & 2007 & Australia & Commentary & $\begin{array}{ll}- & \text { Colonisation } \\
- & \text { Indigenous Rights and Self- } \\
& \text { Determination }\end{array}$ \\
\hline $\begin{array}{l}\text { 2. Australian Institute } \\
\text { of Health and } \\
\text { Welfare }\end{array}$ & 2016 & Australia & $\begin{array}{l}\text { Government } \\
\text { Report }\end{array}$ & $\begin{array}{ll}\text { - } & \text { Role of Government } \\
\text { - Social Determinants of } \\
\text { Indigenous Health } \\
\text { - Indigenous Rights and Self- } \\
\text { Determination }\end{array}$ \\
\hline $\begin{array}{l}\text { 3. Bishop, Vicary, } \\
\text { Browne, \& Guard }\end{array}$ & 2009 & Australia & $\begin{array}{l}\text { Peer-Reviewed } \\
\text { Case Study }\end{array}$ & $\begin{array}{ll}\text { - } & \text { Colonisation } \\
\text { - Indigenous Rights and Self- } \\
\text { Determination }\end{array}$ \\
\hline 4. Black \& McBean & 2016 & Canada & $\begin{array}{l}\text { Peer-Reviewed } \\
\text { Policy Analysis }\end{array}$ & $\begin{array}{l}\text { - Colonisation } \\
\text { - Social Determinants of } \\
\text { Indigenous Health } \\
\text { - Indigenous Rights and Self- } \\
\text { Determination }\end{array}$ \\
\hline 5. Brown & 2009 & Australia & $\begin{array}{l}\text { Peer-Reviewed } \\
\text { Policy Literature } \\
\text { Review }\end{array}$ & $\begin{array}{ll}\text { - } & \text { Colonisation } \\
\text { - } & \text { Mainstream Services } \\
\text { - Indigenous Rights and Self- } \\
\text { Determination }\end{array}$ \\
\hline $\begin{array}{l}\text { 6. Browne, de Leeuw, } \\
\text { Gleeson, Adams, } \\
\text { Atkinson, \& Hayes }\end{array}$ & 2017 & Australia & $\begin{array}{l}\text { Peer-Reviewed } \\
\text { Policy Analysis }\end{array}$ & $\begin{array}{ll}\text { - } & \text { Colonisation } \\
\text { - } & \text { Mainstream Services } \\
\text { - } & \text { Indigenoul Determinants of } \\
& \text { Health }\end{array}$ \\
\hline 7. Cooke \& McWhirter & 2011 & Canada & $\begin{array}{l}\text { Peer-Reviewed } \\
\text { Policy Analysis }\end{array}$ & $\begin{array}{ll}\text { - } & \text { Colonisation } \\
\text { - } & \text { Mainstream Services }\end{array}$ \\
\hline 8. Cooper & 2011 & Australia & $\begin{array}{l}\text { Non- } \\
\text { Government } \\
\text { Report }\end{array}$ & $\begin{array}{l}\text { - } \text { Colonisation } \\
\text { - } \text { Role of Government } \\
\text { - } \quad \text { Social Determinants of } \\
\text { - Indigenous Health } \\
\text { - Indigenous Rights and Self- } \\
\text { Determination }\end{array}$ \\
\hline
\end{tabular}


Table 2. Summary of Sources Included in the Analysis (continued)

\begin{tabular}{|c|c|c|c|c|}
\hline Author & Date & Country & Source Type & Themes Identified \\
\hline 9. Cox & 2011 & Australia & Commentary & $\begin{array}{ll}\text { - } & \text { Colonisation } \\
\text { - } & \text { Role of Government }\end{array}$ \\
\hline $\begin{array}{l}\text { 10. Dwyer, Boulton, } \\
\text { Lavoie, Tenbensel, \& } \\
\text { Cumming }\end{array}$ & 2014 & $\begin{array}{l}\text { Canada, } \\
\text { New } \\
\text { Zealand, } \\
\text { and } \\
\text { Australia }\end{array}$ & $\begin{array}{l}\text { Peer-Reviewed } \\
\text { Policy Analysis }\end{array}$ & $\begin{array}{ll}\text { - } & \text { Colonisation } \\
\text { - } & \text { Role of Government } \\
\text { - } & \text { Mainstream Services }\end{array}$ \\
\hline $\begin{array}{l}\text { 11. Fisher, Battams, } \\
\text { McDermott, Baum, } \\
\text { \& MacDougall }\end{array}$ & 2018 & Australia & $\begin{array}{l}\text { Peer-Reviewed } \\
\text { Policy Analysis }\end{array}$ & $\begin{array}{l}\text { - Role of Government } \\
\text { - Social Determinants of } \\
\text { Health } \\
\text { - Indigenous Rights and Self- } \\
\text { Determination }\end{array}$ \\
\hline 12. Hill & 2008 & $\begin{array}{l}\text { United } \\
\text { States }\end{array}$ & $\begin{array}{l}\text { Peer-Reviewed } \\
\text { Policy Literature } \\
\text { Review }\end{array}$ & - Colonisation \\
\hline 13. Hudson & 2009 & Australia & $\begin{array}{l}\text { Non- } \\
\text { Government } \\
\text { Report }\end{array}$ & - Role of Government \\
\hline $\begin{array}{l}\text { 14. Kelaher, Sabanovic, } \\
\text { La Brooy, Lock, } \\
\text { Uddin, \& Brown }\end{array}$ & 2015 & Australia & $\begin{array}{l}\text { Non- } \\
\text { Government } \\
\text { Report }\end{array}$ & $\begin{array}{l}\text { - Role of Government } \\
\text { - Indigenous Rights and Self- } \\
\text { Determination }\end{array}$ \\
\hline 15. Kelly & 2011 & Canada & $\begin{array}{l}\text { Peer-Reviewed } \\
\text { Policy Analysis }\end{array}$ & $\begin{array}{l}\text { - Colonisation } \\
\text { - Role of Government } \\
\text { - Indigenous Rights and Self- } \\
\text { Determination }\end{array}$ \\
\hline 16. Klein & 2015 & Australia & $\begin{array}{l}\text { Non- } \\
\text { Government } \\
\text { Report }\end{array}$ & $\begin{array}{ll}\text { - } & \text { Colonisation } \\
\text { - } & \text { Mainstream Services } \\
\text { - } & \text { Social Determinants of } \\
\text { Indigenous Health } \\
\text { - Indigenous Rights and Self- } \\
\text { Determination }\end{array}$ \\
\hline
\end{tabular}


Table 2. Summary of Sources Included in the Analysis (continued)

\begin{tabular}{|c|c|c|c|c|}
\hline Author & Date & Country & Source Type & Themes Identified \\
\hline $\begin{array}{l}\text { 17. Lavoie, Boulton, \& } \\
\text { Gervais }\end{array}$ & 2012 & $\begin{array}{l}\text { Canada \& } \\
\text { New } \\
\text { Zealand }\end{array}$ & $\begin{array}{l}\text { Peer-Reviewed } \\
\text { Policy Analysis }\end{array}$ & $\begin{array}{ll}- & \text { Colonisation } \\
\text { - } & \text { Indigenous Rights and Self- } \\
& \text { Determination }\end{array}$ \\
\hline 18. Lavoie & 2014 & $\begin{array}{l}\text { Canada } \\
\text { and } \\
\text { Norway }\end{array}$ & $\begin{array}{l}\text { Peer-Reviewed } \\
\text { Policy Analysis }\end{array}$ & $\begin{array}{ll}\text { - } & \text { Colonisation } \\
\text { - } & \text { Mainstream Services } \\
\text { - } & \text { Indigenous Rights and Self- } \\
\text { Determination }\end{array}$ \\
\hline 19. Lavoie \& Dwyer & 2016 & $\begin{array}{l}\text { Canada } \\
\text { and } \\
\text { Australia }\end{array}$ & $\begin{array}{l}\text { Peer-Reviewed } \\
\text { Policy Analysis }\end{array}$ & $\begin{array}{l}\text { - } \text { Colonisation } \\
\text { - Role of Government } \\
\text { - Indigenous Rights and Self- } \\
\text { Determination }\end{array}$ \\
\hline 20. Lawrence & 2013 & Australia & Commentary & - Colonisation \\
\hline $\begin{array}{l}\text { 21. Lindstedt, Moeller- } \\
\text { Saxone, Black, } \\
\text { Herrman, \& Szwarc }\end{array}$ & 2017 & Australia & $\begin{array}{l}\text { Peer-Reviewed } \\
\text { Policy Analysis }\end{array}$ & $\begin{array}{ll}\text { - } & \text { Colonisation } \\
\text { - } & \text { Social Determinants of } \\
& \text { Indigenous Health }\end{array}$ \\
\hline $\begin{array}{l}\text { 22. Meo-Sewabu \& } \\
\text { Walsh-Tapiata }\end{array}$ & 2012 & $\begin{array}{l}\text { New } \\
\text { Zealand \& } \\
\text { Fiji }\end{array}$ & $\begin{array}{l}\text { Peer-Reviewed } \\
\text { Policy Analysis }\end{array}$ & $\begin{array}{ll}\text { - } & \text { Colonisation } \\
\text { - Indigenous Rights and Self- } \\
\text { Determination }\end{array}$ \\
\hline 23. Mitchell \& Macleod & 2014 & Canada & $\begin{array}{l}\text { Peer-Reviewed } \\
\text { Policy Analysis }\end{array}$ & $\begin{array}{ll}\text { - } & \text { Colonisation } \\
\text { - Indigenous Rights and Self- } \\
\text { Determination }\end{array}$ \\
\hline $\begin{array}{l}\text { 24. Munshi, Kurian, } \\
\text { Morrison, \& } \\
\text { Morrison }\end{array}$ & 2016 & $\begin{array}{l}\text { New } \\
\text { Zealand }\end{array}$ & $\begin{array}{l}\text { Peer-Reviewed } \\
\text { Policy Analysis }\end{array}$ & - Colonisation \\
\hline $\begin{array}{l}\text { 25. Robertson, } \\
\text { Conigrave, Ivers, } \\
\text { Usher, \& Clough }\end{array}$ & 2012 & Australia & $\begin{array}{l}\text { Peer-Reviewed } \\
\text { Qualitative } \\
\text { Research }\end{array}$ & $\begin{array}{l}\text { - Colonisation } \\
\text { - Social Determinants of } \\
\text { Indigenous Health } \\
\text { - Indigenous Rights and Self- } \\
\text { Determination }\end{array}$ \\
\hline
\end{tabular}


Table 2. Summary of Sources Included in the Analysis (continued)

\begin{tabular}{|c|c|c|c|c|}
\hline Author & Date & Country & Source Type & Themes Identified \\
\hline 26. Ronald \& Koea & 2013 & $\begin{array}{l}\text { New } \\
\text { Zealand }\end{array}$ & $\begin{array}{l}\text { Edited Book } \\
\text { Chapter }\end{array}$ & $\begin{array}{ll}\text { - } & \text { Colonisation } \\
\text { - } & \text { Mainstream Services } \\
\text { - } & \text { Indigenous Determinants of } \\
\text { - } & \text { Indigenoulth } \\
& \text { Determination }\end{array}$ \\
\hline 27. Russell & 2010 & Australia & Commentary & - Colonisation \\
\hline 28. Shewell & 2016 & Canada & $\begin{array}{l}\text { Peer-Reviewed } \\
\text { Policy Analysis }\end{array}$ & $\begin{array}{ll}\text { - } & \text { Colonisation } \\
\text { - Indigenous Rights and Self- } \\
\text { Determination }\end{array}$ \\
\hline 29. Smith & 2007 & Australia & $\begin{array}{l}\text { Conference } \\
\text { Paper }\end{array}$ & $\begin{array}{l}\text { - } \text { Colonisation } \\
\text { - } \text { Role of Government } \\
\text { - } \text { Mainstream Services } \\
\text { - Social Determinants of } \\
\text { - Indigenous Health } \\
\text { - Indigenous Rights and Self- } \\
\text { Determination }\end{array}$ \\
\hline 30. Stanley & 2011 & Australia & Public Lecture & $\begin{array}{ll}\text { - } & \text { Colonisation } \\
\text { - Indigenous Rights and Self- } \\
\text { Determination }\end{array}$ \\
\hline 31. Sullivan & 2011 & Australia & $\begin{array}{l}\text { Non- } \\
\text { Government } \\
\text { Report }\end{array}$ & $\begin{array}{l}\text { - } \\
\text { - } \text { Mainstream Services } \\
\text { - Indigenous Rights and Self- } \\
\text { Determination }\end{array}$ \\
\hline 32. Unal & 2018 & $\begin{array}{l}\text { United } \\
\text { States }\end{array}$ & $\begin{array}{l}\text { Peer-Reviewed } \\
\text { Policy Analysis }\end{array}$ & $\begin{array}{l}\text { - } \text { Colonisation } \\
\text { - } \text { Role of Government } \\
\text { - } \quad \text { Social Determinants of } \\
\text { Indigenous Health } \\
\text { - Indigenous Rights and Self- } \\
\text { Determination }\end{array}$ \\
\hline
\end{tabular}


Table 2. Summary of Sources Included in the Analysis (continued)

\begin{tabular}{|c|c|c|c|c|}
\hline Author & Date & Country & Source Type & Themes Identified \\
\hline $\begin{array}{l}\text { 33. Victorian Council of } \\
\text { Social Service } \\
\text { (VCOSS) }\end{array}$ & 2016 & Australia & $\begin{array}{l}\text { Non- } \\
\text { Government } \\
\text { Report }\end{array}$ & $\begin{array}{ll}\text { - } & \text { Role of Government } \\
\text { - } & \text { Mainstream Services } \\
\text { - } & \text { Social Determinants of } \\
& \text { Indigenous Health } \\
\text { - Indigenous Rights and Self- } & \text { Determination }\end{array}$ \\
\hline 34. Wilmot & 2018 & Canada & $\begin{array}{l}\text { Peer-Reviewed } \\
\text { Policy Analysis }\end{array}$ & $\begin{array}{l}\text { - } \text { Colonisation } \\
\text { - } \text { Role of Government } \\
\text { - } \quad \text { Social Determinants of } \\
\text { - Indigenous Health } \\
\text { - Indigenous Rights and Self- } \\
\text { Determination }\end{array}$ \\
\hline
\end{tabular}

\section{Theme 1: Colonisation Past and Present}

Multiple authors viewed colonisation as a determinant of the health of Indigenous Peoples with multiple adverse impacts (Brown, 2009; Klein, 2015; Lavoie, 2014; Lavoie \& Dwyer, 2016; Munshi, Kurian, Morrison, \& Morrison, 2016; Wilmot, 2018). Unal (2018) explained that colonisers to the United States of America drew on doctrines of discovery and conquest to dispossess Indigenous Peoples from land and to challenge sovereign rights. Cooper (2011) argued that colonial policies that dislocate Indigenous Peoples from their homelands, prevent Indigenous self-determination, undermine economic and social development, and fragment families are directly linked to the poor health of Indigenous children globally. Following from this, he surmised that Australian policies have assumed control of the lives of Aboriginal people, resulting in "increased feelings of frustration, disempowerment, stress and anxiety and the associated incidence of chronic illness" (p. 11).

In addition, Black and McBean (2016) described colonisation as destructive, with far reaching consequences for Aboriginal Peoples in Canada. Peer-reviewed literature from both Australia (Bishop et al., 2009; Brown, 2009; Browne et al., 2017; Lindstedt, Moeller-Saxone, Black, Herrman, \& Szwarc, 2017; Robertson et al., 2012; Stanley, 2008) and Canada (Cooke \& McWhirter, 2011; Mitchell \& Macleod, 2014; Shewell, 2016) described the damage caused by past policies of segregation, marginalisation, and assimilation. One particularly damaging characteristic of colonisation described was the forced removal of Indigenous children from families in Australia, the United States, and Canada (Black \& McBean, 2016; Brown, 2009; Hill, 2008; Lavoie, 2014; Mitchell \& Macleod, 2014; Shewell, 2016; Unal, 2018). Bishop et al. (2009) argued that Aboriginal children are still removed from families in Australia, but in a more sophisticated manner through the welfare system, noting that while current policies are written to focus on "child welfare" rather than forced removal, Aboriginal children are "still 
removed at a rate over six times more than non-Aboriginal children" (p. 113). Lindstedt et al. (2017) stated that in 2015 Aboriginal and Torres Strait Islander children were living in out of home care at a rate of 52.5 per 1000 children, compared to 8.1 per 1000 children for the total population, indicating the rate of removal was 9 times more likely for Indigenous children.

The grey literature from the non-government sector also recognised ongoing impacts of colonisation. Klein (2015) described Australian policies as paternalistic, directive, and deficit based. D. Smith (2007) argued coercion is a policy instrument to enable government control over Aboriginal people, and this has disempowered Indigenous Peoples since colonisation. She argued that "the history of Indigenous Affairs in Australia shows that coercion rarely leads to sustained positive outcomes. On the contrary, often it has led to unintended consequences that have exacerbated problems and created profound misery on the ground" (p. 7). An example of "failed policy" (Russell, 2010) attributed to ongoing colonisation was the Australian government's Northern Territory Emergency Response (Anderson, 2007; Cooper, 2011; Cox, 2011; Lawrence, 2013; D. Smith, 2007), about which Brown (2009) stated that "developments in the Northern Territory demonstrate that governments are still willing to exercise strict and punitive controls over Aboriginal individuals and communities" (p. 1563).

Black and McBean (2016) argued that decolonisation in policy would reflect a more holistic approach to addressing the health concerns of Indigenous communities. There were five sources that drew attention to decolonisation in policy through the Treaty of Waitangi in New Zealand; this included the three sources that focused on policy in New Zealand and two other comparative studies (Dwyer, Boulton, Lavoie, Tenbensel, \& Cumming, 2014; Lavoie, Boulton, \& Gervais, 2012; Meo-Sewabu \& WalshTapiata, 2012; Munshi et al., 2016; Ronald \& Koea, 2013). Lavoie (2014) explained that New Zealand was the final British colony to be settled and this government was committed to avoiding the complex and violent experiences of other colonies, and Maori people were able to exert their sovereign rights (Ronald \& Koea, 2013). As a result, integration was prioritised over marginalisation or containment, and this led to the Treaty of Waitangi. This treaty helps incorporate Maori values and ideology into social and health policies. The Maori concept of whanau ora (family health) has become a priority for health services promoting a focus on well-being more aligned with an Indigenous definition of health (Dwyer et al., 2014). The Treaty of Waitangi provides an example of policy that does not represent Indigenous Peoples as a policy problem. While the policy implications of the Treaty remain contested (Ronald \& Koea, 2013), it has been shown to provide a framework for collaboration (Carter et al., 2009) because consultation with Maori on policy matters is required by law (Munshi et al., 2016). Ronald and Koea (2013) explained, "any discussion concerning the health of Maori in modern society must consider the historical, cultural and social context in which Maori have arrived in the $21^{\text {st }}$ century" (p. 173). Maori people have fought for their right to self-determination since the Treaty was first signed in 1840. MeoSewabu and Walsh-Tapiata (2012) highlighted that there are lessons to be learned from Maori advocates who have "determinedly reclaimed and revitalised many aspects of their culture in order to preserve and transfer these to future generations" (p. 306). They argued that cultural preservation is essential, and policy must incorporate a commitment to human rights and an Indigenous concept of health and well-being. Unal (2018) described treaties with Indigenous people in the United States as a cornerstone of policy, but further explained that they have been limited in reach and time. These treaties do not carry the same weight as the New Zealand Treaty of Waitangi because implementation is discretionary and shaped by funding rather than community need. 
The Canadian policy context is built upon treaty obligations; whereby the government has an obligation to assume responsibility for the health of First Nations people (Lavoie \& Dwyer, 2016). In addition, Canadian constitutional recognition acknowledges the rights of First Nations, Inuit, and Métis to selfgovernment. Wilmot (2018) explained that this provides a foundation for decolonisation with the potential to improve cultural sensitivity with the health care system and include more holistic and collective approaches to health and well-being. Kelly (2011), Lavoie and Dwyer (2016), and Wilmot (2018) all recognised that there has been a shift in Canadian policy from assimilation towards advocacy and self-governance, especially in the Province of British Columbia. However, Wilmot (2018) argued that the legacy of colonialism remains a barrier to implementing decolonising policy because First Nations people continue to be perceived as "inferior and exotic" and "health care for First Nations people has been seen as a separate, marginal matter" (p. 13).

\section{Theme 2: Role of Government}

In addition to criticism of colonial policies and their enduring effects, there was also criticism of contemporary policy implementation and the role of government, which added to our understanding of how problem representations have come about. Unal (2018) explained Indigenous health policy has a "long, complicated and often turbulent history... resulting in complicated interactions between federal, state, tribal, and other programs with various funding sources and systems of governance" (p. 267). Kelly (2011) attributed jurisdictional gaps and longstanding debate between levels of government to the uncoordinated and fragmented health system. Cooper (2011) argued that policy created in "silos" leads to poorly coordinated objectives and outcomes across government departments. Cox (2011) suggested that Australian policies have been ineffective and not often evaluated. Kelaher et al. (2015) maintained that policy evaluations have concentrated on the achievement of defined outcomes at the expense of process. More specifically, Sullivan (2011) described national Australian policies such as the National Indigenous Reform Agreement as bound by "political shackles" (p. 19). He argued that the structure of these agreements, which tie federal and state governments to each other, has resulted in "solutions" that cannot respond to local problems. Fisher, Battams, McDermott, Baum, and MacDougall (2018) highlighted an exception to this in Australia in the National Aboriginal and Torres Strait Islander Health Plan. In this policy, community control and partnership between Indigenous leaders and the government was seen as a priority, which contrasted Indigenous leaders' assessment of past policy processes (including the National Indigenous Reform Agreement) in which attempts to form partnerships were inadequate. Fisher et al. (2018) argued that this leadership and advocacy was cruicial in the successul intergration of social determinants of Indigneous health into national health policy. D. Smith (2007) noted that government has a role in creating broader complex policy processes that are reflected in the unnecessary multiplication of programs and onerous funding processes. She argued that governments have not recognised the "extent to which government funding arrangements have exacerbated community and organisational dysfunction and poor governance" (p. 11). Hudson (2009) suggested that these funding complexities make accountability impossible and that "fewer than half of the Aboriginal health services file annual reports or complete their financial reporting requirements" ( $\mathrm{p}$. 1). In addition, accountability was described in the literature as primarily one-way where recipients of funding are accountable for the spending and outcomes. However, Dwyer et al. (2014) argued that tensions concerning accountability have deep roots in perspectives that problematize Indigenous Peoples. They advocated for an alternative understanding of accountability where identity is negotiated, and obligations and commitments are reciprocal. Wilmot (2018) agreed that reciprocal accountability 
would support collaboration and a transformation agenda away from colonising policy. Other literature highlighted a call for long-term funding (Anderson, 2007; Australian Institute of Health and Welfare, 2016; Cooper, 2011; Dwyer et al., 2014; Kelly, 2011; Lavoie \& Dwyer, 2016) that would incorporate sustained and consistent effort across government (Victorian Council of Social Service, 2016) and reflect a stronger commitment to action on social determinants of health, which in turn would address issues of health inequity.

\section{Theme 3: Mainstream Services}

The literature described an expectation from the Australian, New Zealand, and Canadian governments that mainstream health services respond to the needs of Indigenous Peoples (Brown, 2009; Browne et al., 2017; Ronald \& Koea, 2013; Victorian Council of Social Service, 2016) and the assumption that if this occurred Indigenous Peoples would then be more likely to use these services (Cooke \& McWhirter, 2011; Cooper, 2011; Klein, 2015; Sullivan, 2011). Many discussions from "mainstream services" continue to contest both of these ideas and represent Indigenous people as a policy problem. Even when mainstream services adopt targeted strategies to meet needs of the Indigenous community, it can reflect a cheap, underfunded version of welfare that does not meet expectations of the community or the organisations (Lavoie, 2014). In an example from New Zealand, Maori people had concerns that mainstream services offered superficial appeasement, or at worst appropriation, of traditional customs, protocol, and culture (Ronald \& Koea, 2013). Lavoie (2014) and Unal (2018) described mainstream services as a Western model of health care that excludes traditional health practices. Wilmot (2018) recognised the provision of services in Canada within a mainstream system as having the potential for greater Indigenous participation and closer coordination with community; however, the impact on health and well-being is difficult to quantify. The literature showed that, in the provision of mainstream services, the government decides what the most effective health care is without considering Indigenous knowledge, beliefs, traditions, or customs. This "undermines self-determination, self-government, and the sovereignty of [Indigenous] people” (Unal, 2018, p. 266). In addition, expectations that Indigenous health and well-being is best achieved by integrating people into mainstream services (Klein, 2015) is criticised by Sullivan (2011) as "normalisation." On one hand, normalisation can reflect a commitment to equality whereby all people have equal access to services. On the other hand, however, the process of normalisation undermines diversity and cultural practices and does not take account of how accessible services are to different groups. Sullivan (2011) and Lavoie (2014) both connected this process of normalisation to assimilation. Sullivan (2011) argued that current Australian policies reflect this type of normalisation. Cooper (2011) argued that requiring Aboriginal Peoples to access mainstream services subjects them "to increased levels of government control, surveillance and intervention in the name of addressing disadvantage and community dysfunction” (p. 19). In addition, Dwyer et al. (2014) explained that mainstream service providers are bound by complex funding and report requirements that are subject to increased monitoring by funding bodies. This is another example of how Indigenous Peoples are represented as a problem. D. Smith (2007) suggested that while people may have to access mainstream services, "Indigenous people will never leave their culture to one side; they will not be assimilated” (p. 12). Despite access to mainstream services, Indigenous health and disadvantage has shown little improvement in Australia. Cooper (2011) concluded that the model needs reassessment because there is a silence in policy about alternatives, such as community-controlled health services. 


\section{Theme 4: Social Determinants of Indigenous Health}

Action on social determinants, including cultural determinants, were identified as essential components to improve health in this review (Australian Institute of Health and Welfare, 2016; Black \& McBean, 2016; Cooper, 2011; Klein, 2015; Lindstedt et al., 2017; Robertson et al., 2012; D. Smith, 2007; Sullivan, 2011). Ronald and Koea (2013) described a Maori definition of health that is connected to relationships with one another, community, and the land, which, in their view, is consistent with global Indigenous orientation towards holistic views of health and well-being. Both the article by Browne et al. (2017) and the report by the Victorian Council of Social Service (2016) recognised a holistic view of health and the importance of the social determinants of Indigenous health. However, Browne et al. (2017) highlighted that even though an Aboriginal definition of health may be quoted in policy documents, it does not always lead to holistic approaches to health in policy implementation. Unal (2018) explained that United States federal government acts may have laid a foundation for wideranging community-based health approaches, including social determinants of Indigenous health and self-determination, but implementation is lacking, and there has been no assurance of action on social determinants of Indigenous health. A specific example of policy that has recognised social determinants of Indigenous health is the Australian National Aboriginal and Torres Strait Islander Health Plan. Fisher et al. (2018) described the way that policy actors responded to a window of opportunity to challenge conventional problem definitions and to place social determinants of Indigenous health at the centre of health policy for the first time. Their analysis showed that despite a commitment to partnership and collaboration, this policy was unclear in implementation and was not fully funded. These findings suggest that the representation of Indigenous Peoples as the policy problem overshadows evidence supporting action on social determinants of Indigenous health. When Indigenous knowledge and understanding of health are identified in policy but not acted on, the position of "other" is maintained as interesting but not worthy of action. Wilmot (2018) argued that the devaluing of Indigenous knowledge in the health care system has had a negative impact on health and well-being.

\section{Theme 5: Indigenous Rights and Self-Determination}

There was consensus in the reviewed documents that UNDRIP should call on governments to account for the support of Indigenous rights in policy and practice. Black and McBean (2016) argued that the recognition of Indigenous rights and commitment to self-determination are essential for the health of Aboriginal Peoples. However, existing policies on Indigenous rights appear to be at best incompatible with the Declaration and at worst a violation of rights (Australian Institute of Health and Welfare, 2016; Cooper, 2011; Klein, 2015; Meo-Sewabu \& Walsh-Tapiata, 2012; Mitchell \& Macleod, 2014; Shewell, 2016). Cooper (2011) argued that the Australian government's actions within current policy breech many articles of the Declaration, such as those that refer to control and "Indigenous rights to selfdetermination, participation in policy development and implementation, and the ability to practise and maintain their unique cultures" (p. 2). Shewell (2016) suggested the initial resistance by Australia, New Zealand, Canada, and the United States governments to adopt the Declaration reveals "an inherent, ideological aversion to collective rights" (p. 188). Brown (2009) described self-determination as implemented in Australia as a "failed experiment" (p. 1562). She argued in general terms, without referring to the content of specific policies, that the move to embrace self-determination in Australian policy was conceived without infrastructure or resources to ensure sustainability. As a result, policy makers have continued to view Aboriginal and Torres Strait Islander people from a deficit perspective 
and represent them as policy problems. The outcome of these processes is often policies that contain hollow promises of Indigenous equality and that lack Indigenous political representation. D. Smith (2007) argued that successive Australian governments have fundamentally failed to invest in Indigenous self-governance despite cases in which Indigenous communities successfully "establish[ed] good governance" and thereby "secur[ed] important social, cultural and economic outcomes" (p. 9) using a strengths-based approach. The limited implementation and lack of funding for the National Aboriginal and Torres Strait Islander Health Plan, which included culture at the centre of health policy, is further evidence of the lack of action on policy that promotes social determinants of Indigenous health (Fisher et al., 2018). Lavoie and Dwyer (2016) highlighted that, without a treaty with Indigenous Peoples in Australia, self-determination is not a priority for the Australian government and constitutional reform may be required to fully address issues of governance and health equity.

On balance, the literature suggested that self-determination was lacking in policy. However, there were many examples of policy discussed in the literature that involved forms of engagement between policy makers and Indigenous Peoples. These were described in terms of consultation, collaboration, community engagement, partnership, or participation (Australian Institute of Health and Welfare, 2016; Bishop et al., 2009; Kelaher et al., 2015; Kelly, 2011; Meo-Sewabu \& Walsh-Tapiata, 2012; Robertson et al., 2012; Ronald \& Koea, 2013; Sullivan, 2011; Victorian Council of Social Service, 2016). Some considered Indigenous "voice" in policy as essential for improving health equity, especially given the history of marginalisation (Kelaher et al., 2015; Victorian Council of Social Service, 2016). However, we found in this review that the depth, quality, and purpose of Indigenous engagement in policy are contested and not the same as a commitment to self-determination. Black and McBean (2016) described consultation as a primarily "Western approach to Indigenous involvement" (p. 14) that actually disempowers Aboriginal people, resulting in negative outcomes for health and the environment. For example, Anderson (2007) described past Australian policy as "paternalistic," and it did not demonstrate a true commitment to working collaboratively. Similarly, Lavoie (2014) argued that few health services in Canada include Aboriginal input in decision making, service planning, or design. Strategies described in the literature used to engage with Indigenous Peoples and communities are varied and can be tokenistic (Kelaher et al., 2015). Consultation is a concept that appears to be understood differently by different parties (Australian Institute of Health and Welfare, 2016). Mitchell and Macleod (2014) argued that there is a rhetoric of consultation but a lack of subsequent action. An example from Klein (2015) suggested that consultation has been "more to convince local people of the merit of preconceived policies and principles than to inform the policies themselves, and allow deliberation and community participation" (p. 7). Fisher et al. (2018) also found that, even when policy is driven by consultation and a strength-based approach, action on social determinants of Indigenous health is often left unimplemented or unfunded.

Another approach to policy described in the literature, which would alter the representation of Indigenous Peoples and cultures to a strengths-based view, is the embedding of Indigenous knowledge into policy and action. This is described by Black and McBean (2016) as an important foundation for decolonisation and improving health. They proposed that the inclusion of Indigenous knowledge in policy ensures "the recognition of inherent rights, the ability of Indigenous communities to participate fully and meaningfully in decisions that affect their people, and the transition to self-determination" ( $p$. 7). They advocated for a bottom-up approach to policy; whereby, Indigenous knowledge is respected and sought out by policy makers, which would shift the problem representation away from Indigenous 
Peoples. Wilmot (2018) described the integration of knowledges as an overlapping of boundaries where two cultural worlds interface, are mutually identifiable and reinforced, but also interact. Respecting Indigenous knowledge in this way supports local Indigenous participation in policy making, and implementation can move beyond tokenistic consultation (Kelaher et al., 2015; Klein, 2015; Mitchell \& Macleod, 2014) and paternalistic approaches to policy design and action (Anderson et al., 2007).

\section{Discussion}

The literature in this review showed barriers and limitations to recognising social determinants of Indigenous health and Indigenous rights in policy. The Treaty of Waitangi in New Zealand provided evidence of the way that Maori people have withstood the forces of colonisation and had this recognised in policy. The National Aboriginal and Torres Strait Islander Health Plan in Australia reframed policy problems and deficits and positioned culture at the centre of the policy. However, policy implementation has been inconsistent or tokenistic. The failure of policy action on social determinants of Indigenous health is not a result of a lack of advocacy and resistance to colonisation; rather, it highlights the lack of Indigenous rights and sovereignty in policy, which would support social determinants of Indigenous health. The themes identified in the results of this review all contribute to answering the following questions:

- How are Indigenous Peoples, health, and rights represented as policy problems?

- How have such problem representations come about?

- What are the effects produced by such problem representation in limiting policy goals and strategies, or silencing other alternatives?

The way that problems are framed and represented within policy determines the way that some problem solutions are actioned, and other possibilities are ignored or avoided (Bacchi, 2009). Policies that are paternalistic, directive, and deficit based (Klein, 2015) reflect a position of privilege and power held by policy makers or governments over their constituents. The policy focus on mainstream services for Indigenous people (Brown, 2009; Browne et al., 2017; Cooke \& McWhirter, 2011; Cooper, 2011; Ronald \& Koea, 2013; Unal, 2018) represents the problem as a failure of Indigenous Peoples to fit in with dominant, White social norms and institutions. With a solution that focuses on normalisation (Sullivan, 2011), Indigenous Peoples themselves are represented as the problem. For example, Pholi, Black, and Richards (2009) suggested that the Australian government's Closing the Gap strategy addressing health inequity reduces Aboriginal and Torres Strait Islander people to a set of indicators of deficits monitored by government-set targets where evidence may not be reliable or valid. They explained that the targets measure what is "wrong," what is "known," and how to "fix" Aboriginal and Torres Strait Islander people. This deficit discourse in policy was strongly criticised by Klein (2015) and Sullivan (2011) who explain that Indigenous Peoples and communities are represented as "other." This worldview that sees Indigenous Peoples and cultures as "other" is reflected in health care (Goodman et al., 2017) and in policy (Schofield \& Gilroy, 2015). The exclusion of traditional healers from policy in the United States demonstrates the power of a Western worldview of health in positioning Indigenous knowledge outside of health. Unal (2018) explained that the lack of integration of traditional healers into health policy and service provision resulted in fear and distrust of government run services. The 
systemic racism leading to Indigenous Peoples being represented as "other" is also deeply engrained in society in colonial countries like Australia (Baum, 2015) and Canada (Elliott \& De Leeuw, 2009).

From our Bacchian analysis, we conclude that both historical colonial policies and ongoing policy failings predominantly represent Indigenous Peoples as policy problems that require government intervention to solve. This deficit approach is likely to reduce effectiveness of policy because it silences potential policy actions focused on building resilience and strength within Indigenous cultures (Chandler \& Lalonde, 1998; Victorian Health Promotion Foundation, 2011), which are essential social determinants of Indigenous health. When considering the history of colonisation and the impact on Indigenous Peoples, it becomes clear that this representation of Indigenous Peoples as the problem has been a dominant theme in past policies (Brown, 2009), along with the struggle for self-determination (Kelaher et al., 2015; Klein, 2015; Meo-Sewabu \& Walsh-Tapiata, 2012; Mitchell \& Macleod, 2014; Sullivan, 2011). Colonial policies of segregation, marginalisation, and assimilation have had lasting effects on Indigenous Peoples and the policy environment (Bishop et al., 2009; Brown, 2009; Browne et al., 2017; Cooke \& McWhirter, 2011; Kelly, 2011; Mitchell \& Macleod, 2014; Robertson et al., 2012; Shewell, 2016; Stanley, 2008; Unal, 2018; Wilmot, 2018). This colonial foundation supports the siloed structure of governments (Cooper, 2011; Sullivan, 2011) and ineffective policy (Cox, 2011). Historically, the dominance of a Western-centric approach has restricted sharing and influence of Indigenous knowledge outside of Indigenous communities, elevating colonial powers to a superior position (Goodman et al., 2017; Schofield \& Gilroy, 2015; L. T. Smith, 2012; Wilmot, 2018). This power and ongoing nature of colonisation means the representation of Indigenous people as "other" or as a problem that needs to be fixed continues into current policy without consideration of the strength and importance of Indigenous knowledge. Sherwood (2010) argued that denying Indigenous knowledge further exacerbates the pain and injury caused by colonisation. Even though the literature revealed that collaboration and consultation with Indigenous Peoples is commonly mentioned in policy, the quality of this engagement is inconsistent and a does not constitute self-determination (Black \& McBean, 2016; Klein, 2015; Lavoie, 2014). The process of participation in policy was described as primarily "Western" and as continuing to isolate or marginalise Indigenous Peoples. The examples of top-down policy, where governments hold power over Indigenous Peoples, can result in implementation that does not respond to the needs or strengths of Indigenous Peoples themselves. Government control over the lives of Indigenous Peoples (Cooper, 2011) and use of coercion as a policy instrument (D. Smith, 2007) have a negative impact on health and well-being.

On the question of alternative perspectives missing from policy and policy silences, the inconsistent value placed on an Indigenous view of health and the lack of self-determination suggests that Indigenous rights are missing from policy. Incorporation of rights would provide a normative basis for more effective policy approaches to address Indigenous health inequities within the countries covered by this review. The United Nations Declaration on the Rights of Indigenous Peoples (2007) could have been a catalyst for empowerment and recognition; however, Australia, New Zealand, Canada, and the United States all initially voted against it. Their opposition was in response to the term "self-determination" (Talbot \& Verrinder, 2014), as well as resistance to the recognition of rights as part of current policy. The Australian Human Rights Commission (n.d.) stated that the loss of Indigenous rights is at the heart of Indigenous disadvantage and that "without self-determination it is not possible for Indigenous Australians to fully overcome the legacy of colonisation and dispossession" (Self Determination and Australia's First Peoples section, para. 5). 
Mitchell and Macleod (2014) maintain that policies have often been developed and implemented in ways that are contradictory to the worldview of Aboriginal Peoples. In response to policies that are silent on Indigenous knowledge, Meo-Sewabu and Walsh-Tapiata (2012) in New Zealand called on Indigenous Peoples to look for solutions from "within" that reflect social determinants of Indigenous health. They advocated for policy with meanings, words, and ways of knowing that reflect Indigenous knowledge. In addition, Wilmot (2018) promoted policy at the boundaries of knowledge where different understandings of health can be used to reform health service delivery.

Inevitably, this review of the literature may not have captured all of the relevant literature. The additional sources included through targeted searches in international policy journals, together with sources suggested through peer review, support the comprehensive critique of the literature and problem representation in policy.

\section{Conclusion}

This scoping review of research literature, public policy, and Indigenous health has explored the ways that social determinants of Indigenous health and Indigenous rights are recognised and not recognised in policy. Our analysis showed that policies represent colonial approaches to power and that, while selfdetermination may be included in policy rhetoric, implementation of this principle is inconsistent or non-existent. The themes that emerged from the literature highlighted that colonisation in policy is ongoing. The structure of mainstream service provision in health and encouragement of Indigenous Peoples to use mainstream services was described as problematic for the health of Indigenous Peoples and restrictive of self-determination. The literature supported the important role of government in policy implementation but called for a stronger commitment to Indigenous rights. Collaboration across sectors was shown as an essential component in policy implementation; however, policy actors face challenges working together. The inclusion of social determinants of health in policy has been researched by Carter et al. (2009), Fisher et al. (2016), and Phillips et al. (2016), but a specific analysis on social determinants of Indigenous health would add depth to this field of policy analysis. In addition, research on the realisation of Indigenous of rights in policy implementation would explore the ways in which rights have been written into policy but action has been limited (Cooper, 2011; Shewell, 2016; D. Smith, 2007). The challenge remains for policy makers to support and encourage self-determination and decolonisation through recognition in policy, but also to ensure these commitments are translated into implementation.

\section{References}

Anderson, I. (2007). Unexplained differences. Retrieved from http://apo.org.au/node/5116

Anderson, I., Baum, F., \& Bentley, M. (Eds.). (2007). Beyond bandaids: Exploring the underlying social determiants of Aboriginal health. Darwin, Australia: CRC for Aboriginal Health.

Australian Human Rights Commission. (n.d.). Rights to self determination. Retrieved from https://www.humanrights.gov.au/right-self-determination

Australian Institute of Health and Welfare. (2016). National frameworks about Aboriginal and Torres Strait Islander people. Retrieved from http://apo.org.au/node/71034 
Bacchi, C. L. (2009). Analysing policy: What's the problem represented to be? Frenchs Forest, Australia: Pearson Australia.

Baum, F. (2015). The new public health (4th ed.). South Melbourne: Oxford University Press.

Baum, F., \& Friel, S. (2014). Centres of Research Excellence: Social determinants of health equity. Unpublished grant proposal, Flinders University, Adelaide, South Australia, Australia.

Bishop, B. J., Vicary, D. A., Browne, A. L., \& Guard, N. (2009). Public policy, participation and the third position: The implication of engaging communities on their own terms. American Journal of Community Psychology, 43(1-2), 111-121. doi: https://doi.org/10.1007/s10464-008-9214-8

Black, K., \& McBean, E. (2016). Increased Indigenous participation in environmental decision-making: A policy analysis for the improvement of Indigenous health. The International Indigenous Policy Journal, 7(4), 5. doi: https://doi.org/10.18584/iipj.2016.7.4.5

Brown, N. (2009). History, law, and policy as a foundation for health care delivery for Australian Indigenous children. Pediatric Clinics of North America, 56(6), 1561-1576. doi: https://doi.org/10.1016/j.pcl.2009.10.002

Browne, J., de Leeuw, E., Gleeson, D., Adams, K., Atkinson, P., \& Hayes, R. (2017). A network approach to policy framing: A case study of the National Aboriginal and Torres Strait Islander Health Plan. Social Science \& Medicine, 172, 10-18. doi: https://doi.org/10.1016/j.socscimed.2016.11.011

Carson, B., Dunbar, T., Chenhall, R. D., \& Bailie, R. (Eds.). (2007). Social determinants of Indigenous health. Crows Nest, Australia: Allen and Unwin. doi: https://doi.org/10.1017/s1326011100004567

Carter, S. M., Hooker, C., \& Davey, H. M. (2009). Writing social determinants into and out of cancer control: An assessment of policy practice. Social Science \& Medicine, 68, 1448-1455. doi: http://doi.org/10.1016/j/socscimed.2009.01.029

Chandler, M. J., \& Lalonde, C. (1998). Cultural continuity as a hedge against suicide in Canada's First Nations. Transcultural Psychiatry, 35(2), 191-219. doi: https://doi.org/10.1177/136346159803500202

Comino, E., Knight, J., \& Webster, V. (2012). Risk and protective factors for pregnancy outcomes for urban Aboriginal and non-Aboriginal mothers and infants: The Gudaga cohort. Maternal and Child Health Journal, 16(3), 569-578. doi: https://doi.org/10.1007/s10995-011-0789-6

Commission on the Social Determinants of Health. (2008). Closing the gap in a generation: Health equity through social action on the social determinants of health-Final report of the Commission on Social Determinants of Health. Geneva, Switzerland: World Health Organisation. doi: https://doi.org/10.11606/issn.2316-9044.v10i3p253-266 
Cooke, M., \& McWhirter, J. (2011). Public policy and Aboriginal Peoples in Canada: Taking a lifecourse perspective. Canadian Public Policy-Analyse de Politiques, 37, S15-S31. doi: https://doi.org/10.3138/cpp.37.suppl.s15

Cooper, D. (2011). Closing the gap in cultural understanding: Social determinants of health in Indigenous policy in Australia. Darwin, Australia: Aboriginal Medical Services Alliance of the Northern Territory (AMSANT).

Cox, E. (2011, September 5). Government ignores evidence of policy failure on Aboriginal issues. The Conversation. Retrieved from https://theconversation.com/government-ignores-evidence-ofpolicy-failure-on-aboriginal-issues-3118

Davis, M. (2007, October 3). Australia is not an island. National Indigenous Times. Retrieved from http://www.onlineopinion.com.au/view.asp? article $=6449$ \&page $=0$

Dixon-Woods, M., Agarwal, S., Jones, D., Young, B., \& Sutton, A. (2005). Synthesising qualitative and quantitative evidence: A review of possible methods. Journal of Health Services Research and Policy, 1O(1), 45-53. doi: https://doi.org/10.1258/1355819052801804

Durie, M. (1985). A Maori perspective of health. Social Science \& Medicine, 20(5), 483-486. doi: https://doi.org/10.1016/0277-9536(85)90363-6

Durie, M. (2005). Indigenous knowledge within a global knowledge system. Higher Education Policy, 18, 301-312. doi: https://doi.org/10.1057/palgrave.hep.8300092

Dwyer, J., Boulton, A., Lavoie, J. G., Tenbensel, T., \& Cumming, J. (2014). Indigenous Peoples' health care: New approaches to contracting and accountability at the public administration frontier. Public Management Review, 16(8), 1091. doi: https://doi.org/10.1080/14719037.2013.868507

Dwyer, J., Kelly, J., Willis, E., \& Mackean, T. (2011). Managing two worlds together (Reports 1-4). Melbourne, Australia: The Lowitja Institute.

Elliott, C. T., \& De Leeuw, S. N. (2009). Our Aboriginal relations when family doctors and Aboriginal patients meet. Canadian Family Physician, 55(4), 443-444.

Fisher, M., Battams, S., McDermott, D., Baum, F., \& MacDougall, C. (2018). How the social determinants of Indigenous health became policy reality for Australia's National Aboriginal and Torres Strait Islander Health Plan. Journal of Social Policy, 48(1) 1-21. doi: https://doi.org/10.1017/S0047279418000338

Fisher, M., Baum, F. E., MacDougall, C., Newman, L., \& McDermott, D. (2016). To what extent do Australian health policy documents address social determinants of health and health equity? Journal of Social Policy, 45(3), 545-564. doi: https://doi.org/10.1017/S0047279415000756

Goodman, A., Fleming, K., Markwick, N., Morrison, T., Lagimodiere, L., \& Kerr, T. (2017). “They treated me like crap and I know it was because I was Native": The healthcare experiences of 
Aboriginal peoples living in Vancouver's inner city. Social Science \& Medicine, 178, 87-94. doi: https://doi.org/10.1016/j.socscimed.2017.01.053

Grenier, L. (1998). Working with Indigenous knowledge: A guide for researchers. Retrieved from https://idl-bnc-idrc.dspacedirect.org/bitstream/handle/10625/16526/IDL16526.pdf? sequence $=9$ \&isAllowed $=y$

Hart, M. A. (2010). Indigenous worldviews, knowledge and research: The development of an Indigenous research paradigm. Journal of Indigenous Voices in Social Work, 1(1), 1-16.

Healey, J. (2014). Indigenous rights. Thirroul, Australia: The Spinney Press.

Hernandez, M. (2012). The politics of knowledge in policy analysis. Pimatisiwin: A Journal of Aboriginal and Indigenous Community Health, 10(2), 153-160.

Hill, R. B. (2008). Gaps in research and public policies. Child Welfare, $87(2), 359-367$.

Hudson, S. (2009). Closing the accountability gap: The first step towards better Indigenous health. Retrieved from http://apo.org.au/node/19935

Jackson Pulver, L., Haswell, M. R., Ring, I., Waldon, J., Clark, W., Whetung, V., .. S Sadana, R. (2010). Indigenous health-Australia, Canada, Aotearoa New Zealand and the United States - Laying claim to a future that embraces health for us all. Retrieved from http://www.who.int/healthsystems/topics/financing/healthreport/IHNo33.pdf

Kelaher, M., Sabanovic, H., La Brooy, C., Lock, M., Uddin, S., \& Brown, L. (2015). Planning implementation and effectiveness in Indigenous health reform. Melbourne, Australia: The Lowitja Institute.

Kelly, M. D. (2011). Toward a new era of policy: Health care service delivery to First Nations. The International Indigenous Policy Journal, 2(1). doi: https://doi.org/10.18584/iipj.2011.2.1.11

Klein, E. (2015). A critical review of the capability approach in Australian Indigenous policy. Canberra, Australia: Centre for Aboriginal Economic Policy Research, Australian National University.

Lavoie, J. G. (2014). Policy and practice options for equitable access to primary healthcare for Indigenous Peoples in British Columbia and Norway. The International Indigenous Policy Journal, 5(1), 6. doi: https://doi.org/10.18584/iipj.2014.5.1.6

Lavoie, J. G., Boulton, A., \& Gervais, L. (2012). Regionalization as an opportunity for meaningful Indigenous participation in healthcare: Comparing Canada and New Zealand. The International Indigenous Policy Journal, 3(1), 1-14. doi: https://doi.org/10.1854/iipj.2012.3.1.2

Lavoie, J. G., \& Dwyer, J. (2016). Implementing Indigenous community control in health care: Lessons from Canada. Australian Health Review, 40, 453-458. 
Lawrence, C. (2013). Aboriginal health and the Australian Constitution: How do we fix them both? Australian and New Zealand Journal of Public Health, 37(2), 108-110. doi: https://doi.org/10.1111/1753-6405.12026

Levesque, A., \& Li, H. Z. (2014). The relationship between culture, health conceptions, and health practices: A qualitative-quantitative approach. Journal of Cross-Cultural Psychology, 45(4), 628-645. doi: https://doi.org/10.1177/0022022113519855

Levesque, A., Li, H. Z., \& Bohemier, M. (2013). Cultural variations in health conceptions: A qualitative approach. Pimatisiwin: A Journal of Aboriginal and Indigenous Community Health, 11(2), 215229.

Lindstedt, S., Moeller-Saxone, K., Black, C., Herrman, H., \& Szwarc, J. (2017). Realist review of programs, policies, and interventions to enhance the social, emotional, and spiritual well-being of Aboriginal and Torres Strait Islander young people living in out-of-home care. The International Indigenous Policy Journal, 8(3). doi: https://doi.org/10.18584/iipj.2017.8.3.5

Meo-Sewabu, L., \& Walsh-Tapiata, W. (2012). Global declaration and village discourses: Social policy and Indigenous wellbeing. AlterNative: An International Journal of Indigenous Peoples, 8(3), 305-317. doi: https://doi.org/10.1177/117718011200800306

Mitchell, T., \& Macleod, T. (2014). Aboriginal social policy: A critical community mental health issue. Canadian Journal of Community Mental Health, 33(1), 109-122. doi: https://doi.org/10.7870/cjcmh-2014-010

Munshi, D., Kurian, P. A., Morrison, T., \& Morrison, S. L. (2016). Redesigning the architecture of policy-making: Engaging with Maori on nanotechnology in New Zealand. Public Understanding of Science, 25(3), 287-302. doi: https://doi.org/10.1177/0936662514548629

National Aboriginal Community Controlled Health Organisation. (2006). Definitions. Retrieved from http://www.naccho.org.au/about/aboriginal-health/definitions/

Osborne, K., Baum, F., \& Brown, L. (2013). What works? A review of actions addressing the social and economic determinants of Indigenous health. Retrieved from https://www.aihw.gov.au/reports/indigenous-australians/what-works-a-review-of-actionsaddressing-the-social-and-economic-determinants-of-indigenous-health/contents/table-ofcontents

Peters, M. D., Godfrey, C., M., Khalil, H., McInerney, P., Parker, D., \& Soares, C. B. (2015). Guidance for conducting systemic scoping reviews. International Journal of Evidence-Based Healthcare, 13, 141-146. doi: https://doi.org/10.1097/XEB.0000000000000050

Phillips, C., Fisher, M., Baum, F., MacDougall, C., Newman, L., \& McDermott, D. (2016). To what extent do Australian child and youth health policies address the social determinants of health 
and health equity? A document analysis study. BMC Public Health, 16(1). doi: https://doi.org/10.1186/s12889-016-3187-6

Pholi, K., Black, D., \& Richards, C. (2009). Is 'Closing the Gap' a useful approach to improving the health and wellbeing of Indigenous Australians? Australian Review of Public Affairs, 9(2), 1-13.

Robertson, J. A., Conigrave, K. M., Ivers, R., Usher, K., \& Clough, A. R. (2012). Translation of tobacco policy into practice in disadvantaged and marginalized subpopulations: A study of challenges and opportunities in remote Australian Indigenous communities. Health Research Policy and Systems, 10(23). doi: https://doi.org/10.1186/1478-4505-10-23

Ronald, M., \& Koea, J. (2013). Social policy and Indigenous health: Lessons from New Zealand. In M. W. Popejoy \& C. Akukwe (Eds.), Global Public Health Policy (pp. 173-192). Hauppauge, NY: Nova Science Publishers.

Russell, L. M. (2010). Indigenous health checks: A failed policy in need of scrutiny. Retrieved from http://apo.org.au/node/23301

Saks, M., \& Allsop, J. (2007). Researching health: Qualitative, quantiative and mixed methods. London, England: Sage Publications.

Schofield, T., \& Gilroy, J. (2015). Indigeneity and health. In T. Schofield (Ed.), A sociological approach to health determinants (pp. 99-122). Port Melbourne, Australia: Cambridge University Press. doi: https://doi.org/10.1017/cbo9781316178713.006

Sherwood, J. (2010). Do no harm: Decolonising Aboriginal health research (Doctoral dissertation). Retrieved from http://unsworks.unsw.edu.au/fapi/datastream/unsworks:8457/SOURCE02?view=true

Shewell, H. (2016). Why jurisdiction matters: Social policy, social services and First Nations. Canadian Journal of Native Studies, 36(1), 179-202.

Smith, D. (2007, June). From COAG to coercion: A story of governance failure, success and opportunity in Australian Indigenous Affairs. Paper presented at the Governing Through Collaboration: Managing Better Through Others conference, Canberra, Australia.

Smith, L. T. (2012). Decolonizing methodologies research and Indigenous Peoples (2nd ed.). New York, NY: Zed Books.

Stanley, F. (2008, November). The greatest injustice: Why we have failed to improve the health of Aboriginal people. Paper presented at the 2008 Annual Hawke Lecture, Adelaide, Australia. Retrieved from http://apo.org.au/node/4327

Sullivan, P. (2011). The policy goal of normalisation, the National Indigenous Reform Agreement and Indigenous National Partnership Agreements. Retrieved from http://www.nintione.com.au/resource/NintiOneWorkingPaper 76 PolicyGoalofNormalisati on.pdf 
Talbot, L., \& Verrinder, G. (2014). Promoting health: The primary health care approach. Chatswood, Australia: Elsevier Australia.

Tynan, M. (2013). Anthropology, community development, and public policy: The case of the Kaiela Planning Council. Collaborative Anthropologies, 6, 307-333.

doi: https://doi.org/10.1353/cla.2013.0009

Unal, D. (2018). Sovereignty and social justice: How the concepts affect federal American Indian policy and American Indian health. Social Work in Public Health, 33(4), 259-270.

doi: https://doi.org/10.1080/19371918.2018.1462287

United Nations. (2007). Declaration on the Rights of Indigenous Peoples. Retrieved from http://www.un.org/esa/socdev/unpfii/documents/DRIPS en.pdf

Victorian Council of Social Service. (2016). Improving Aboriginal health and wellbeing: VCOSS submission to the strategic plan discussion guide. Melbourne, Australia: Victorian Council of Social Service.

Victorian Health Promotion Foundation. (2011). Life is health is life: Taking action to close the gap: Victorian Aboriginal evidence-based health promotion resource. Carlton, Australia: Victoria Department of Health.

Wilmot, S. (2018). Transforming First Nations health care in British Columbia: An organizational challenge. The International Indigenous Policy Journal, $9(1)$.

doi: https://doi.org/10.18584/iipj.2018.9.1.4

Ziersch, A., Gallaher, G., Baum, F., \& Bentley, M. (2011). Racism, social resources and mental health for Aboriginal people living in Adelaide. Australian and New Zealand Journal of Public Health, 35(3), 231-237. doi: https://doi.org/10.1111/j.1753-6405.2011.00681.x 